\title{
良導絡測定で興奮抑制の出現しなかった症例
} 後 藤 公 哉*

\section{Cases of the appearance neither excitation nor inhibition in Ryodoraku measurement.}

KIMIYA GOTO:

Director of East Japan Branch on Japan Society of Ryodoraku Medicine

The most important characteristic of Ryodoraku therapy is Total Ryodoraku Measurement and Tonification or Sedation point Therapy is one of the most important elements in General Regulation Therapy (GRT) of Ryodoraku.

This time I encounter cases which patients complain symptoms but there are no excitation or Inhibition points out of Physiological Range on their Ryodoraku Chart.

There are three kinds of Total Ryodoraku Therapy, one is Basic"regulating therapy and another is Tonification or Sedation Point Therapy on the other hand, there is Reactive Electro Conductive Points (RECP) Therapy. It has been explained all of them should be gone through the procedure; General Regulation Therapy (GRT) of Ryodoraku would be completed.

I have question whether it could be omitted of Tonification or Sedation Point Therapy or not, for effective result, on special case. Then I report inspection for three case omitted G.R.T. First case indicates only $11 \mu \mathrm{A}$. Even it measured on Magnified Measurement, second is taken antidepressant, and third is wearing Minus-ionic-Mask on patient' $s$ mouse.

On the result, symptoms are decreased on three cases. According with basic regulating point' $s$ therapy, Reactive Electro Conductive Points (RECP) therapy on symptom conceming Rypdoraku, and experienced point therapy.

【はじめに】

良導絡治療の最大特徴は全良導絡測定にあ る。症状を訴えて来院した患者が、良導絡チ ヤート上に興抑を現さない症例に遭遇する。
全良導絡調整療法の中で興雀点抑制点の治療 は大切な治療法の 1 つである。興抑点治療を 行わなかった症例を報告する。

\footnotetext{
*後藤鋮炎整体療院 テ221-0076 横浜市神奈川区白幡町2-8 TEL 045(401) 3917 FAX 045(401) 7389

Eメール go0101@mx4.mesh.ne.jp

キーワード：良導絡測定 無興奮無抑制 基本調整点治療
} 


\section{【目的・対象】}

良導絡治療には基本調整点治療と興奮点抑 制点治療の全良導絡調整法と反応良導点治療 がある。興奮点抑制点治療を行わなくても効 果があるものかどうか、測定結果が生理的範 囲から逸脱しなかった、拡大測定、抗整剤服 用、マイナスイオンマスクク装着の 3 症例を 報告する。

\section{【症例 I 】}

94才 + 主訴：変形性膝関節症 初診時：1 ケ月前夕食後に手足に力が入ら
なくなった、血圧は190-100 $\mathrm{mm} / \mathrm{Hg}$ 、病院に 1 週間入院点滴治療、今は降圧剂で安定して いる。両膝が階段昇降時痛、膝間 4 横指、 $\mathrm{O}$ 脚から変形膝関節症と思われる。大腿四頭筋 強化のため、下肢 $30^{\circ}$ 挙上を指示。

高血圧、耳鳴り、めまい、口乾、足腰だる い、頭痛、目がほやける等から肝腎陰虚と思 われる（1。

初診時良導絡チャート：12V測定では $10 \mu$ A以下で興抑が出現しないため、21V拡大測 定を行った（図 1 図 2 。

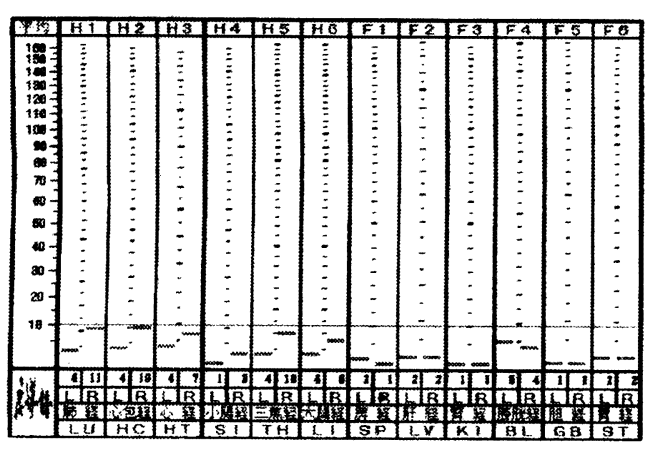

図1：初診時12V測定 平均值 $4 \mu \mathrm{A} \quad \mathrm{H}$ 采 $5 \mu \mathrm{A} \quad \mathrm{F}$ 采 $3 \mu \mathrm{A}$

治療：基本調整点 $\mathrm{V}$ 型（2。膝周囲の反応 良導点、EX (下梁丘)、EX (下血海)、EX

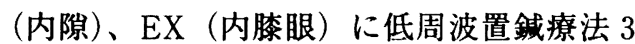
Hz20分間。H5-5 (外関)、F4-8 (崑崙)、F19 (陰陵泉)、F4-37 (肝俞)、F4-32（腎兪） に置鍼10分間。

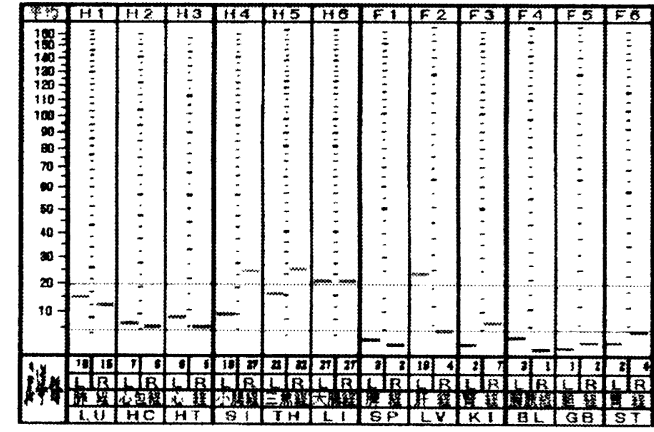

図 2：21V拉大湖定 平均值 $11 \mu \mathrm{A} \quad \mathrm{H}$ 采 $17 \mu \mathrm{A} \quad \mathrm{F}$ 系 $4 \mu \mathrm{A}$

$\mathrm{H} 4$ (小腸) H5（リンパ） H6（大腸）の抑 制点、F1（脾）F3 (腎) F4（膀胱）F5（胆） F6（胃）の興奮点を使用せずに、手足の反 応良導点、H5-5（外関）、F1-6（三陰交）、 F5-10（陽交）の経穴を使用した。

治療：同様治療後、21診時、膝痛改善、良

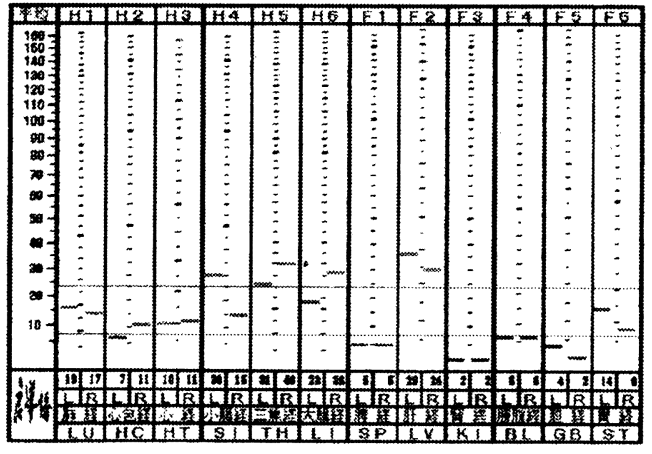

図 3：15診時 平均値 $15 \mu \mathrm{A} \quad \mathrm{H}$ 系 $21 \mu \mathrm{A} \quad \mathrm{F}$ 系9 $\mu \mathrm{A}$

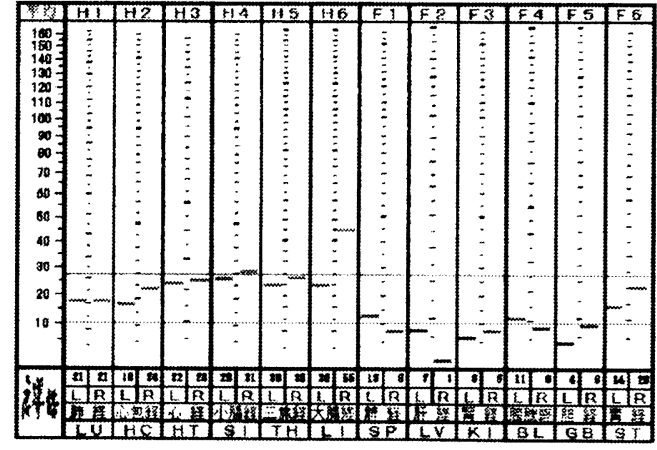

図 4：21診時 平均値 $19 \mu \mathrm{A} \quad \mathrm{H}$ 系 $28 \mu \mathrm{A} \quad \mathrm{F}$ 系9 $\mu \mathrm{A}$ 
導絡平均値も $4 \mu \mathrm{A}$ から $19 \mu \mathrm{A}$ に改善した (図 4 。

\section{【症例 II 】}

$$
62 才 \text { 垂主訴: 肩こり }
$$

初診時：頸肩のこり、血圧を病院で測定す ると緊張からか $160-90 \mathrm{~mm} / \mathrm{Hg}$ と何時も高く
なる。立ち仕事、食欲減退、腹部膨満、無気 力、倦急感、顔のつやがないことから脾気虚 と思われる（3。

初診時良導絡チャート：H4（小腸） H5 (リンパ） H6（大腸）の興奮、F2（肝）F3 (腎) F5（胆）の抑制が著明であった（図 5 。

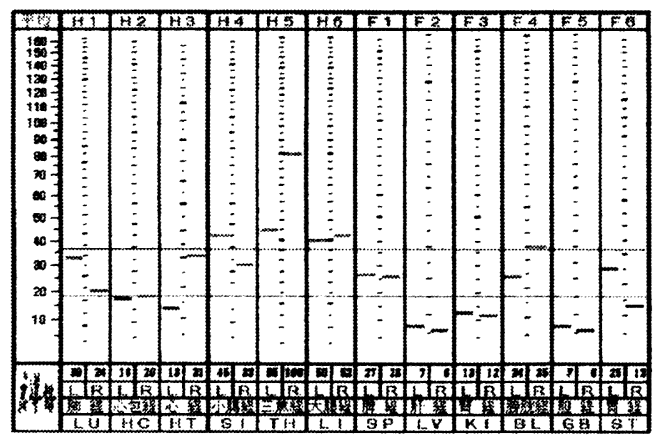

图 5：初診時 平均値 $28 \mu \mathrm{A} \mathrm{H}$ 系 $40 \mu \mathrm{A} \quad \mathrm{F}$ 系17A

治療：基本調整点治療 $\mathrm{V}$ 型に興奮抑制点治 療。F4-59（天柱）、F5-25（風池）、F5-24

(肩井)、H4-11 (天宗)、F4-37 (肝俞)、H5-9 （四瀆）に低周波置針療法 $3 \mathrm{~Hz} 20$ 分間。一般 的な良導絡治療で症状と良導絡チャートの改 善がみられた（図6。

1 年半ぶりに再来院時：主訴が頸肩のこ

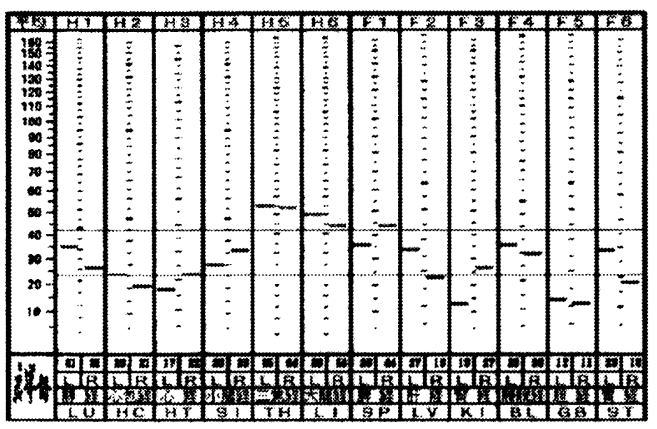

図 6：6 診時 平均値 $32 \mu \mathrm{A} \quad \mathrm{H}$ 系39 $\mu \mathrm{A} \quad \mathrm{F}$ 系 $25 \mu \mathrm{A}$

り、血圧 $140-80 \mathrm{~mm} / \mathrm{Hg}$ 、風邪から咳と肩こ りがひどいと訴える。

再診時良導絡チャート：咳がでる為に天然 鉣石を練り込んだ特殊加工のフィルターか ら、マイナスイオンが発生するマスクをした ままでの測定の為か、測定值の興抑が出現し なかったものと考えられる。（図 7 。

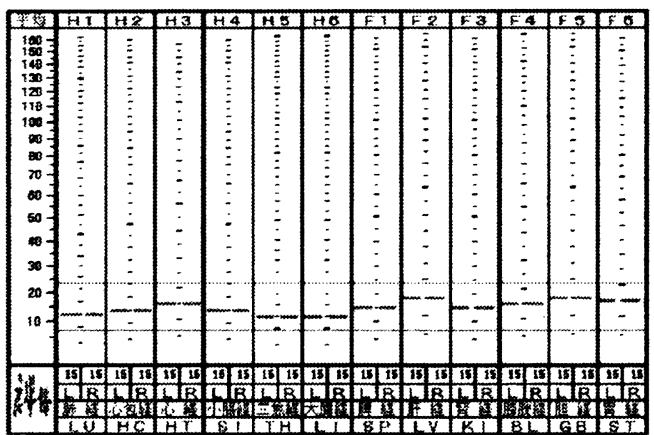

図 7 ：再診時 平均値： $15 \mu \mathrm{A} \mathrm{H}$ 系 $15 \mu \mathrm{A} \quad \mathrm{F}$ 系 $15 \mu \mathrm{A}$

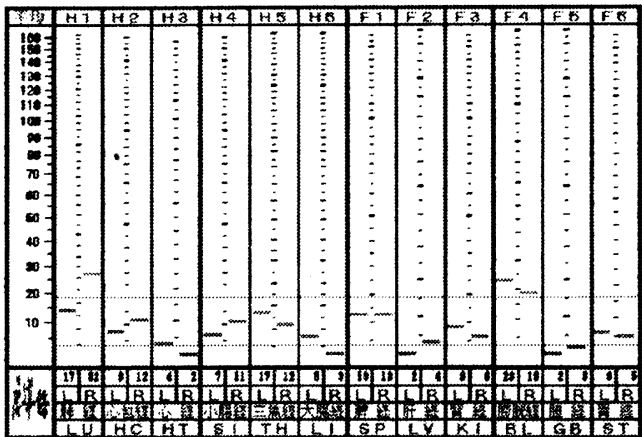

図 8：2診時 平均值：10 $\mu \mathrm{A} \mathrm{H}$ 系 $11 \mu \mathrm{A} \quad \mathrm{F}$ 系9 $\mu \mathrm{A}$ 
治療：基本調整点治療 $\mathrm{V}$ 型。肩こり風邪の 改善に頝肩背部の反応良導点、F4-59 (天柱)、 F5-25（風池）、F5-24（肩井）、F4-43（風門）、 F4-42（肺俞）、F4-37（肝俞）に低周波置針 療法 $3 \mathrm{~Hz} 20$ 分間。咳の改善に手の反応良導 点、H1-8 (尺沢)、H1-6 (孔最) に置針10分。 2 診時：翌日マイナスイオンマスクをはず して測定を行った。
良導絡チャート：H1（肺）F4（膀胱）の 興奮、 $\mathrm{H} 3$ (心) $\mathrm{H} 6$ (大腸) F2 (肝) F5（胆） の抑制が出現した（図8。

治療：前回と同样の治療を行い、H3（心） $\mathrm{H} 6$ (大腸) F2（肝） F5（胆）の興奮点、 $\mathrm{H} 1$ （肺） F4（膀胱）の抑制点の治療は行わなか った。

4 診時：咳、頸肩のこりと症状が改善した。

\begin{tabular}{|c|c|c|c|c|c|c|c|c|c|c|c|c|c|c|c|c|c|c|c|c|c|c|c|c|c|c|c|}
\hline \multicolumn{28}{|c|}{ 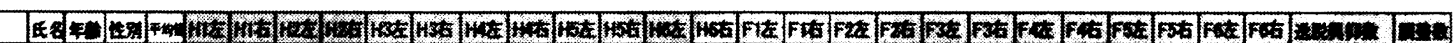 } \\
\hline Ht & i11 $73 / 6$ & (18) & 36 & 43 & 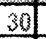 & 21 & & 18 & 29 & & & & 40 & 32 & & 10 & & & & & 17 & & & & 16 & & \\
\hline & 10 分傮 & 30 & 40 & 27 & 37. & 28 & 20 & 19 & 54 & 47 & 48 & 56 & 61 & 7. & 19 & 14 & 31 & & 4 & & 19 & 19 & 13 & $\varepsilon$ & उa & $34\left(\begin{array}{lll}3+2 & 7+1\end{array}\right.$ & \\
\hline & 304 & 21 & 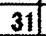 & 3 & 7 & II & 24 & 18 & 50 & 20 & 28 & 36 & 27 & 4 & 18 & 12 & 17 & & & & 23 & 24 & & & 23 & & \\
\hline ar & 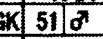 & 28 & 27 & 25 & 30 & 23 & 19 & 21 & 28 & 16 & 36 & 15 & 24 & 24 & 22 & 31 & & 30 & 15 & 26 & 30 & 45 & & 7 & 29 & 3) & \\
\hline & 10分後 & 21 & 22 & 4 & 21 & 35 & 10 & & 17 & 20 & 21) & 30 & 13 & 15 & 291 & 27 & & 93 & 20 & 20 & 14 & 22 & & 23 & & & \\
\hline & 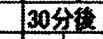 & 20 & 38 & 27 & 31 & 30 & 23 & 24 & 30 & 18 & 21 & 19 & 15 & 23 & 22 & 12 & & 19 & 11 & 10 & 15 & 23 & & & 10 & $23|-34-1|$ & \\
\hline & \begin{tabular}{l|l|l|}
$T$ & 37 \\
\end{tabular} & 80 & 107 & 100 & 75 & 90 & 87 & 72 & 07 & 69 & 87 & 104 & 94 & 90 & 57. & 55 & & 80 & 84 & 92 & 56 & 49 & 9 & 73 & 72 & 35 & \\
\hline & 10 分传 & 77 & 104 & 110 & 77 & 83 & 89 & 82 & 0 & 86 & 84 & 88 & 66 & 88 & 52 & 61 & 68 & 81 & 88 & 89 & 34 & 60 & 87 & 70 & 89 & $8 / 3-3-2$ & \\
\hline & 30 分後 & 52 & 64 & 68 & 49 & 59 & 60 & 46 & 65 & 46 & 88) & 77 & 8 & 68 & 31 & 18 & 41 & S0। & 52 & 58 & 20 & 29 & 44 & 37 & 37 & $58 \mid 3-14-1$ & \\
\hline 101 & Tा 379 & 53 & 55 & 95 & 51 & 76 & 77 & 71 & 28 & 15 & 23 & 24 & 39 & 28 & 57. & 63 & 54 & 29 & 87 & 72 & 76 & 73 & 39 & 39 & 28 & 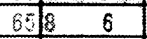 & \\
\hline & 10 分後 & 55 & 71 & 81 & 57 & 68 & 73 & 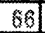 & 57 & 27 & 32 & 31 & 40 & 53 & 54 & 01 & 43 & 50 & 7. & 74 & 70 & 81 & 35 & 35 & 48 & $57 ?-5-1$ & \\
\hline & 304 & 58 & 60 & 109 & 56 & 71 & 77 & 51 & 30 & 32 & 34 & 37 & 42 & 75 & 63 & 63 & 36 & 33. & 52 & 64 & 74 & 30 & 20 & 26 & 40 & 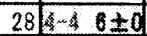 & \\
\hline 5 YYT & T $51 \%$ & 24 & 0 & $5 \%$ & 5 & 33 & 26 & 44 & & 24 & 24 & 50 & 54 & 46 & 31 & 4 & $\infty$ & 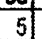 & - & & 32 & 29 & & $\frac{5}{4}$ & 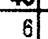 & $9 / 4$ & \\
\hline & 10 公綡 & 24 & 4 & 51 & 26 & 40 & 21 & 27 & 33 & 17 & 24 & 44 & 43 & 33 & 22 & 23 & & & 3 & & 28 & 37 & & & 22 & \begin{tabular}{c|c}
$05+6-3$ \\
\end{tabular} & \\
\hline & $304)^{3}$ & 28 & 45 & 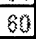 & 9 & 29 & 26 & 31 & 36 & 23 & 28 & 50 & 50 & 34 & 31 & 27 & 9 & 0 & 12 & & 33 & 35 & & & 19 & $23(3-15-4$ & \\
\hline B KT & $\begin{array}{l}\text { T] } 49 \sqrt{3} \\
\end{array}$ & 44 & 62 & 79 & 47 & 57 & 40 & 48 & 23 & 39 & 86 & 56 & 82 & & 41 & 47 & 32 & 5: & 13 & 24 & 64 & 21 & & $\frac{12}{12}$ & 22 & $25 \%$ & \\
\hline & 10 分 & 31 & 24 & 48 & 19 & 21 & 16 & 22 & 24 & 13 & . & 51 & 40 & 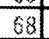 & 36 & 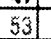 & 24 & 29 & 16 & 21 & $6 \hat{0}$ & 36 & & 13 & 30 & 18. $-2-26-2$ & \\
\hline & 30 分後 & 21 & 24 & 30 & 33 & 3 & 18 & 22 & & 14 & 18 & 28 & 19 & 23 & 36 & 31 & 16 & 12 & 11 & & $50 \mid$ & 31 & & & 20 & $8|3-3 \quad 3-5|$ & \\
\hline $7 \mathrm{SN}$ & 1 2719 & 28 & 22 & 29 & 20 & 23 & 22 & 20 & 27 & 43 & 45 & sol & 66 & 5 & 32 & 35 & 18 & 24 & 15 & 15 & 20 & 20 & & & 12 & 285 & \\
\hline & 10分徏 & 32 & 32 & 29 & -1 & 22 & 28 & 35 & 31 & 35 & 31 & 87 & 5 & 89 & 18 & 10 & 20 & 28 & 15 & 12 & 18 & & & & 36 & \begin{tabular}{|c|c|c|}
$36+6$ & $4-1$
\end{tabular} & \\
\hline & 30 公摞 & 22 & 20 & 22 & 10 & 28 & 10 & 11 & 4 & 10 & 23 & 17 & 22 & 10 & 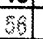 & 40 & Aी & 29 & 23 & 24 & 28 & (3) & & 16 & 18 & $263-23-2$ & \\
\hline 8 GK & \begin{tabular}{c|c|c|}
599.7 \\
\end{tabular} & 8 & 13 & 8 & & 11 & 8 & 5 & & 3 & 4 & 18 & 11 & 7 & 18 & 10 & 8 & & 2 & 1 & 20 & 14 & & 0 & & 62 & \\
\hline & 10 分摞 & 8 & 7 & 8 & 7] & 7 & 8 & 9 & 7 & o & 1 & 13 & 10 & 8 & 18 & 10 & 10 & 13 & 3 & 4 & 13 & & & 4] & & & \\
\hline & 30 分䖽 & & 9 & 4 & 4) & 8 & 6 & & 2 & 6 & 1 & 16 & 8 & 13 & 8 & 8 & 4 & 8 & & & 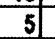 & 20 & & & 23 & $142 \pm 04+2$ & \\
\hline & $27 \%$ & 57 & 64 & 88 & 69 & 104 & 71 & $y$ & 69 & 62 & 82 & 77 & 78 & 66 & 86 & 31 & 40 & 44 & 36 & 34 & 33 & 40 & 29 & 20 & 57 & & \\
\hline & 10 分後 & 68 & 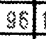 & 18 & 109 & 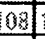 & 23 & & 57 & 61 & 98 & 90 & 70 & 78 & 32 & 44 & 52 & 51 & 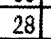 & 30 & 49 & 42 & 27 & 21 & 50 & $476+36+1$ & \\
\hline & 30 分福 & 8 & 109 & 4 & 19 & 39 & 11 & 98 & 117 & 83 & 113 & 112 & 961 & 109 & 57 & 85 & 53 & 6 & 61 & 67 & 65 & 19 & 33 & & 4 & $624+13-2$ & \\
\hline & N $54.0^{7}$ & 23 & 28 & 25 & 31 & 23 & 20 & 22 & 36 & 11 & 23 & 20 & 10 & 11 & 25 & $\frac{32}{32}$ & 23 & 35 & 16 & 15 & 23 & 18 & 17 & 17 & 35 & $23 / 3$ & \\
\hline & 10 分得 & 18 & 12 & & 16 & 4 & 17) & 13 & 9 & 3 & 24 & 25 & 17 & & 28 & 23 & 24 & & 27 & 15 & 32 & 18 & 10 & 17 & 25 & \begin{tabular}{|l|l|l|}
13 & $4+1$ & $3-1$ \\
\end{tabular} & \\
\hline & 30 公展 & (1i) & 7 & & 5) & 4] & 9. & 8 & 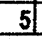 & 5 & 16 & 23 & $n$ & & 27 & 43 & 8 & & 11 & 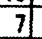 & 15 & & 4 & & 10 & & \\
\hline & & & & & & & & & & & & & & & & & & & & & & & & & & $\begin{array}{ll}16 & 15 \\
\end{array}$ & 23 \\
\hline
\end{tabular}

図 9

マイナスイオンマスク装着

【参考】

マイナスイオンマスク装着が、良導絡チャ ートに影響があるかの検証を行った。

対象は患者 3 名、鍼尒師 7 名。男性 7 名、 女性 3 名。

結果：良導絡平均值の上昇 3 例、変化なし 1 例、下降 6 名であった。興抑の調整が 9 例 (33ヶ所)、興抑の増加1例（ 2 ヶ所）であっ た（図 9 。

マイナスイオンマスク装着により良導絡チ
ヤートの興抑が調整されることは、自律神経 になんらかの影響を与えるものと考えられ る。

\section{【症例 III 】}

年期障害

49歳 え 主訴：腰痛後に男の更

初診時： 1 週間前から起床後に腰痛、座位 から立位で腎俞付近が痛む。怒りっぽい、頭 痛、顔面紅潮、不眠、足腰がたるい、舌紅か 
ら肝陽上妄と思われる（3。

初診時良導絡チャート：F3（腎）F4（膀 胱）抑制があり腰痛の他に、平均值 $73 \mu \mathrm{A}$ と 良導絡測定值のバラツキが大きいことから自 律神経失調症とも思われる（図10。

治療：全良導絡調整療法 $\mathrm{V}$ 型。腰痛改善に
F4-37 (肝俞)、F4-32 (腎俞)、F4-47 (志室)、

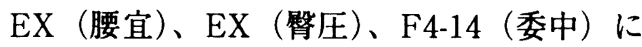
低周波置鋮療法 $3 \mathrm{~Hz} 、 20$ 分間。一般的な良 導絡治療である基本調整点治療に興奮点、抑 制点の治療を行った。腰痛は 1 回の治療で痛 みが改善した。

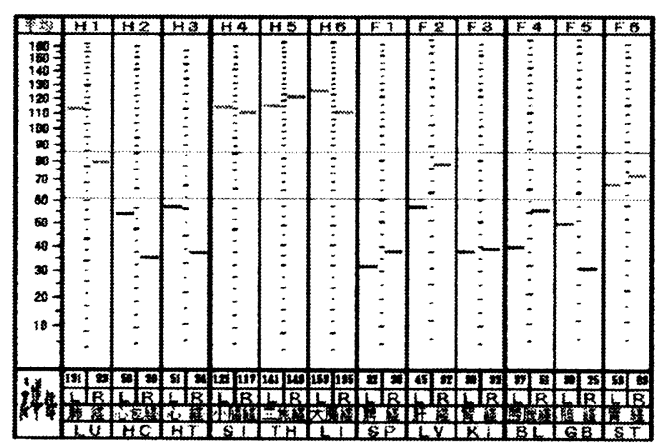

図10：初診時 平均值 $73 \mu \mathrm{A} 、 \mathrm{H}$ 系 $102 \mu \mathrm{A} 、 \mathrm{~F}$ 系 $44 \mu \mathrm{A}$ 、

再診時：腰痛はないが、 5 ケ月間不定愁訴 があり、過労、自律神経失調、䙪病とかたづ けられてドクターショッピング、抗榔剤と安 定剤を服用している。1 週間前風邪からか身 体がだるく足が重い、病院の血液検査は異常 がない、身体がだるく救急車をよびたい感じ と訴える。症状が不安定、不眠、イライラ、 焦燥感の精神神経症状と勃起不全、全身倦怠 感の男性度症状の他、頻尿、残尿感の泌尿器 症状などの男の更年期の3大症状があり、更 年期障害ではと考えホルモン補充療法を説明

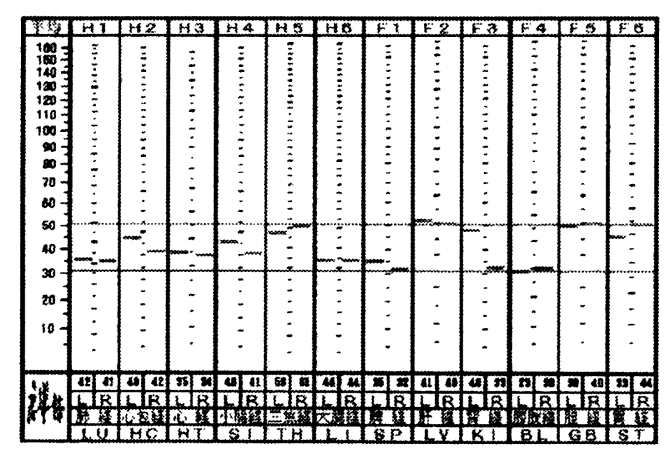

図11：再診時 平均値 $41 \mu \mathrm{A} \mathrm{H}$ 系 $45 \mu \mathrm{A} \quad \mathrm{F}$ 系 $38 \mu \mathrm{A}$ 、

するも癌が心配と訴える。

再診時良導絡チャート：抗䅹剂服用の影響 か良導絡チャート上では興抑の変化が現れな かった（図11。

治療：基本調整点治療 $\mathrm{V}$ 型。肩背部の反応 良導点、F4-59（天柱）、F5-24（肩井）、F437 (肝俞)、F4-32 (腎俞)、F4-47 (志室)、 F4-23 (次彨) に低周波置鍼療法 $3 \mathrm{~Hz} 20$ 分間。 心因性を考えHM26（百会）、VM16（膻中）、 H2-4 (内関)、H3-3（神門）に置鍼15分間。 興奮点抑制点の治療は行わなかった。

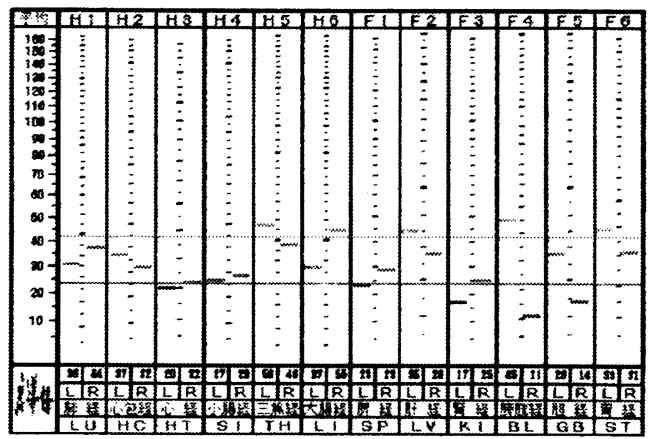

図12：12診時 平均値32 $\mu \mathrm{A} \quad \mathrm{H}$ 系37 $\mu \mathrm{A} \quad \mathrm{F}$ 系27 $\mu \mathrm{A}$

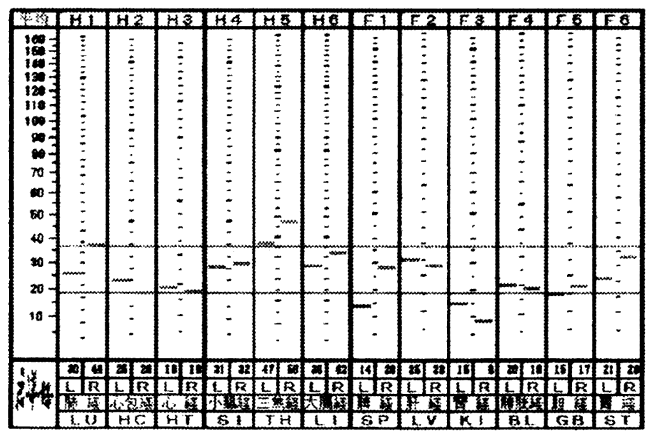

図13：18診時 平均值27 $\mu \mathrm{A} \quad \mathrm{H}$ 系34 $\mu \mathrm{A} \quad \mathrm{F}$ 系20 $\mu \mathrm{A}$ 
12 診時：病院で更年期障害と診断された。 仕事が不動産業で接客にも対人恐怖と不安 感、集中力、食欲、性欲もなくイライラ、微 熱 $37^{\circ}$ で運動もできない、以前はジョギング してサウナに入り、ビールを飲むのが楽しみ であったが、飲む気も出ない。薬の副作用か 頬と胸に薬疹が発生した。抗㯱剤が机モンに影 㸷している可能性もあり、病院で抗㮾唷を中 止するように指示された。

12診時良導絡チャート：H5（リンパ） H6 （大腸）F2（肝）F4（膀胱）F6（胃）興奮、 F1 (脾) F3 (腎) F5 (胆) 抑制が出現した (図12。

治療: 基本調整V型。F4-59（天柱）、F524 (肩井)、F4-37 (肝俞)、F4-32（腎俞）、 F4-47 (志室)、F4-23 (次彨) の反応良導点 に低周波置鍼療法3Hz20分間。HM26 (百会)、 VM16 (膻中)、H2-4 (内関)、F1-8 (地機)、 VM-2（中極）、F3-7（腹溜）に置鏚15分間。 18診時：治療後に気分が良く少しずつ改善し ている。頸肩がはって早朝覚醒、顔が赤く足 が冷たい。

治療：基本調整点 V型。F4-59（天柱）、 F5-24（肩井）、F4-32（腎俞）、F6-10（足三 里)、F3-7 (腹溜) の反応良導点に低周波置 銊療法3Hz20分間。HM26（百会）、F1-6（三 陰交)、H2-4 (内関)、H3-3 (神門)、VM16 (膻中)、F3-26（神蔵）に置鋮10分。

18診時良導絡チャート：H5（リンパ）興 奮、F1（脾）F3 (腎) 抑制があるがバラツ キが改善した（図13。

ホルモン補充療法を継続していても症状を くりかえすが、良導絡治療を行うと症状が軽 減する。

西洋医学的処置を併用することにより効果 をあげた症例であった。

\section{【結 果】}

興奮抑制の出現しなかった 3 症例では、基本 調整点治療 $\mathrm{V}$ 型に症状と関連のある良導絡の 反応良導点治療と、経験的に知られている良 導点の治療を行なったことにより、症状が軽 減した。

\section{【考 察】}

良導絡測定で平均值が $10 \mu \mathrm{A}$ 以下で、興抑 が現れない場合は、21Vでの拡大測定により 興抑を出し治療を行うと中谷は教えている。 抗栕剤、精神安定剤などの服用、マイナスイ オンマスク装着により、良導絡チャート上に 表現出来ない場合の治療法は、いままでに記 載されていない。興抑点治療は、それぞれの 良導絡について考えた部位で、興抑点が定め られている。身体全体と比較してみると、1 ヶ所に刺激を与えると全身の電気抵抗が大き く変動をする。一般の治療刺激によって各良 導絡は自律神経の恒常性の働きによって生理 的な状態にする作用があり、この恒常性の作 用が自然良能力であり健康を維持し病気を治 す原動力となるものと考えられる（4。3 症 例では、基本調整点治療 $\mathrm{V}$ 型の刺激を行った ことにより、恒常性の働きが現れ症状軽隇し たものと思われる。

\section{【おわりに】}

全良導絡測定では時計、金属は外して測定 を行っている。良導絡測定値をチャート上に プロットした際、興奮抑制点が出現しない場 合は、患者に薬の服用や他に健康グッズ等の 装着の有無を確かめる必要がある。興奮点抑 制点は井穴や痛い部位が定められていて臨床 上使用しづらい、測定結果が生理的範囲にお さまっている場合は基本調整点治療の必要性 の他、症状と関係する良導絡上の反応良導点 に治療を行うことで、充分に効果があがるも のと考えられる。症例集積を今後の課題とし たい。

\section{参考文献}

1）神戸中医学研究会訳（1988）、中医学基礎上 海中医学院稨、燎原書店、p250-251

2）後藤公哉（1999）、良導絡療法基礎と臨床 エンタープライズ (株)、p33

3）内山恵子（1988）、中医診断学ノート、東洋 学術出版社、P102 P118

4）中谷義雄（1977）、良導絡自律神経調整療法、 良導絡研究所、P99、P103-104 